\title{
COMUNICARE ȘI COMUNIUNE. BISERICA ŞI LIMBAJUL EI ÎN SOCIETATE Editorial
}

Dumitru A. VANCA ${ }^{1}$

Prezentul volum strânge laolaltă o parte dintre comunicările studenților doctoranzi prezentate în cadrul Școlii Internaționale de Vară a Doctoranzilor Teologi (cunoscută sub abrevierea SIVDT 2019). Eveniment ajuns la a VII-a ediție, întrunirea științifică anuală, organizată de Școala Doctorală de Teologie Ortodoxă din Universitatea „1 Decembrie 1918”, este deja una dintre manifestările științifice cunoscute și așteptate de către tinerii studenți doctoranzi din întreaga țară. Sub patronajul Facultății de Teologie Ortodoxă din Alba Iulia, cu sprijinul logistic al Universității „1 Decembrie 1918” și cel financiar al Consiliului Județean Alba, SIVDT 2019 a primit binecuvântarea Înaltpreasfințitului Părinte Irineu, Arhiepiscopul Alba Iuliei. Nu putem să nu ne exprimăm recunoștința noastră față de obștea Mănăstirii „Sfântul Mare Mucenic Dimitrie" din Sighișoara, în special părintelui stareț, care ne-a pus la dispoziție spațiile de întruniri, trapeza mânăstirii și o parte din spațiile de cazare pentru cei aproape 100 participanţi.

Manifestarea a început, cum este firesc, prin săvârșirea Sfintei Liturghii, urmată de un Te-Deum în biserica mânăstirii. În sesiunea de deschidere au fost transmise mesajul și binecuvântarea Înaltpreasfințitului Părinte Arhiepiscop Irineu, prin Pr. Oliviu BOTOI, Consilier cultural al Eparhiei Alba Iuliei, și au adresat cuvinte de salut decanul Facultăţii de Teologie Ortodoxă și Directorul IOSUD-UAB, și un cuvânt duhovnicesc părintele Ghelasie ȚEPEȘ, starețul Mânăstirii Sfântului Dimitrie.

Având ca temă generală Comunicare şi comuniune. Biserica şi limbajul ei în societate, întâlnirea a fost propusă tinerilor cercetători ca o

1 Preot, profesor, directorul Școlii Doctorale de Teologie din cadrul Universității „1 Decembrie 1918” din Alba Iulia. 
platformă de dezbateri, dialog și polemică științifică a doctoranzilor din țară şi din străinătate, din domeniul studiilor teologice. Întrucât experiența anilor trecuți ne-a făcut să înțelegem că o unică temă este mult prea restrictivă, mai ales pentru cei care nu au cercetări precise pe tema sugerată de Sfântul Sinod al Bisericii Ortodoxe Române - Anul omagial al satului românesc (al preoților, învățătorilor și primarilor gospodari) și Anul comemorativ al Patriarhilor Nicodim Munteanu și Iustin Moisescu și al traducătorilor de cărți bisericești în Patriarhia Românăorganizatorii au permis participanţilor și prezentarea unor comunicări axate pe propriile cercetări. Din acest motiv, în paginile acestui număr (primul dintr-o serie de trei volume găzduite de revista Altarul Reîntregirii), cititorii pot găsi și alte teme, nu doar cele care au ca obiect al cercetării satul românesc ori traducătorii de cărți bisericești.

Gândită nu doar ca o reuniune științifică, ci și ca un eveniment didactic pentru instruirea şi antrenarea cercetătorilor din domeniul „teologie" în activități utile în munca de cercetare, întâlnirea de la Sighişoara, din 7-9 iulie 2019, a găzduit și șapte importante workshop-uri destinate unor aspecte complementare activității de cercetare-publicare: Creativitate şi 'scandal' în discursul teologic contemporan. Vocaţia logosiatică a omului [Emil Jurcan, UAB]; The Moderation in Iconography and Theology [Mariyan STOYADINOV, Universitatea „Sfinţii Kiril şi Metodiu", Veliko Târnovo, Bulgaria]; Ştiinţele umaniste şi cercetarea doctorală din România. Date statistice, analize scientometrice şi oportunităţi de studiu (Mihai GLIGOR, directorul IOSUD UAB); Evaluarea tezelor de doctorat (evaluarea rapoartelor de progres ştiinţific, evaluarea tezei în cadrul comisiei de îndrumare, prezentarea tezei şi evaluarea in cadrul CNATDCU) [Mihai HIMCINSCHI, UAB]; Comunicarea publică a rezultatelor cercetării: tehnici şi metode (Maximizarea vizibilității tinerilor cercetători) [Dumitru A. VANCA, UAB]; Teorii şi aplicaţii de psihologia comunicării în cercetarea teologică [Ovidiu PANAITE, UAB]; Folosirea resursele WEB în cercetarea teologică, [Mihail K. QARAMAH, UAB).

Căutând să împărtășească doctoranzilor din experiența lor în domeniul cercetării, cadrele didactice și îndrumătorii de doctorat au suștinut 12 comunicări științifice pe teme din propriile sfere de cercetare. Acestea au fost: Mihai HIMCINSCHI (UAB): Misiune şi limbaj religios; 
Marian VÎLCIU (Universitatea „Valahia”): Sfânta Euharistie, Taina Bisericii şi a comuniunii cu Hristos - realități liturgice şi pastorale; Gheorghe REMETE (UAB): Divinitatea Sfintelor Evanghelii; Ştefan FLOREA (Universitatea „Valahia”): Comunicarea - act sacru misionar, $o$ necesitate etică contemporană; Jan NICOLAE (UAB): 'Epilogos': Rugăciunile amvonului în tradiţia bizantină, confirmare euharistică a Liturghiei; Lucian COLDA (UAB): Textul patristic-un text 'specializat'? Fides Patrum - intre morfosintaxa şi norma fidei; Daniel MUNTEANU (UVT): Etica libertății și raționalitatea polifonică a noii creații; Ovidiu PANAITE (UAB): Teologia politică între intelectualismul etic şi „,reflective equilibrium”; Dumitru A. VANCA (UAB): Primirea la Ortodoxie: critica unui text liturgic recent; Florin DOBREI (Universitatea „Aurel Vlaicu”, Arad): Monahismul ortodox ardelean - cultură, slujire şi mărturisire. Studiu de caz: Mânăstirea Prislop; Oliviu BOTOI (UAB): Logosul divin şi cuvintele oamenilor. Valoarea spiritual-morală a comunicării în viziunea mitropolitului Ierotheos Vlachos; Adam DOMIN (UAB): Cântarea bisericească - trăire duhovnicească şi imn.

La Sighişoara au fost prezenți aproape 70 de doctoranzi din toate școlile doctorale de teologie din România. Cercetările prezentate în cele patru paneluri au fost în multe situații foarte diversificate, acoperind subiecte istorice, biblice, de bioetică și morală, misiologie, liturgică, muzică și drept canonic... practic, toate marile teme de cercetare au fost prezente la SIVDT 2019. Exerciţiul științific nu s-a rezumat doar la prezentarea rezultatelor cercetării, ci și la celelalte aspecte care țin de o manifestare științifică, cum sunt moderarea sesiunilor, gestionarea dezbaterilor și a polemicilor pe marginea ideilor exprimate etc.

Deși nu toate materialele prezentate la SIVDT 2019 şi-au găsit locul în paginile revistei Altarul Reîntregirii, ne facem o datorie de onoare prin a menționa, chiar și numai în treacăt, numele tuturor participanților și a comunicărilor prezentate, mulțumindu-le totodată pentru efortul de a fi fost alături de noi, unii dintre ei deplasându-se din centre universitare mai îndepărtate, precum Constanța, Iași sau București. Dată fiind lipsa de omogenitate tematică și dezechilibrul în ceea ce privește distribuția participanților pe școli doctorale, am ales ca prezentarea acestora să fie făcută aleatoriu: 
Daniel CĂMARĂ (UAB), Învăţături religios-morale în cântecele pentru copii ale compozitorului Dumitru Georgescu Kiriac; Adrian MĂRGINEAN (UAB), Opera 'Luceafärul' de N. Bretan - omagiu adus lui Mihai Eminescu la 130 de ani de la moarte; Anghel CIURTIN (UAB), Raporturile Islamului cu teritoriile românești; Ioan NISTOR (UAB), Pelerinaj și putere în religia islamică; Ion DRAGNE (UAB), Misiune și secularizare în gândirea teologului Anastasie Yannoulatos; Călin MAN (ULBS), Etnicitatea euharistică și Ortodoxia românească misionară; Gabi-Alin NICA (UB), Provocări pentru viața spirituală în mediul de lucru corporatist (posibile rezolvări); Bogdan GABOR (UBB), Comunicarea digitală ca modalitate de relaţionare autentică; Marian GROZOIU / Florin MIHAIL (UC), Considerații despre inculturație din perspectivă ortodoxăa; Mihail K. QARAMAH (UAB), Contribuţii la ințelegerea liturghiei românilor din veacul al XVII-lea-ms. BAR rom. 707; Mihail COMĂNOIU (UB), Transumanismul - considerații teologice și etice; Dragoș VOINEA (UAB), Antropologia teologică - temei al eticii ortodoxe; Adrian URSU (ULBS), Patriarhul Iustin Moisescu mărturisitorul păcii; Fulvia HOROBEȚ (UB), Mitul, divinul cultele misterice grecești, filosofia Greciei Antice - temeiuri pentru pedagogia actuală; Cristina BĂLDEAN (UBB), Predarea bazată pe atașament. Perspective noi pentru profesorii de religie; Cristian CIORĂNEANU (UBB), Tânărul în Biserică - între comunicare și comuniune în era digitală; Mihaela JURCAN (UAB), Comunicarea în societate și în Biserică; Ilie MANTA (ULBS), Rolul eredităţii şi al educației în apariția şi dezvoltarea comportamentului (homo)sexual; Ioan HODEAN (UAV), Complexul de inferioritate şi patologia afectului; Rareș RUGE (UAB), Biserica de la comunitate la comuniune. Accesibilitatea şi eficienţa limbajului Bisericii; Mihai POCOL (UAB), Teologie și știință. Simbioză sau contradicție cu privire la teoriile apariției vieții; Paul MUCICHESCU (UAB), 'Desăvârşire' şi 'libertate; $O$ analiză teologică în jurul unui fragment din Adversus Haeresis 4,38; Radu SCÂNTEIE (UAV), Vederea lui Dumnezeu în lumina necreată la Sfântul Grigorie Palama; Cristi CRISTESCU (UB), Har și libertate în gândirea Sfântului Ioan Casian; Adrian LAZĂR (UAB), 'Dedoxaste' în omilia ,Vălul de pe fața lui Moise” și 'metamorphote' în omiliile patristice la Schimbarea la Față ale lui Iacob de Sarugh; Cosmin MAFTEI (UAB), ,,Rugăciunea de foc” a Sfântului Ioan 
Casian şi mişcarea Rugului Aprins: premise pentru un „isihasm laic”; Georgian TUDOR (UAB), Comunicarea în și despre satul românesc în contextul contagiunii culturale europene; Dan VÎRBAN (UAB), Spiritualitatea Sfântului Siluan Athonitul; Narcis MUNTEANU (UC), Migrarea satului românesc în Europa Occidentală; Adrian NAE (UOC), Vocaţia cultural-filantropică a monahismului contemporan; Alexandru AGIGNOAEI (UAB), Imaginea şi rolul Antihristului în eshatologia populară românească; Ovidiu MURARI (UAV), Izvorul liturgic al vieţii duhovniceşti; Octavian CEOBANU (UAB), Liturghie şi comuniune. Prezenţa Sfintei Treimi în viaţa credincioşilor; Florin VÂNĂTORU (UC), Comuniunea în Sfânta Liturghie a Bisericii noastre; Florin CONSTANTINESCU (UB), Virtutea teologică a iubirii și a fericirii; Florin ILIESCU (UC), Comunicarea verbală privită din perspectiva analizei stilistice a predicii; Alexandru TOTHĂZAN (UAB), Petru Movilă și eforturile sale de păstrare a dreptei credințe în duh de comuniune; Mihai RĂDUCĂ (UB), Some observations regarding clergy and lay communion in the Romanian Orthodox Church; Andrei MOTORA (UAB), Relație şi dialog între Biserica Ortodoxă Română şi Biserica Ortodoxă de Rit Vechi din România; Traian PANAITESCU (UOC), Comuniune și comunicare interetnică în Dobrogea; Marius CĂLDĂRARU (UB), Aportul BOR la incluziunea religioasă și socială a romilor din România; Lia Ramona VLAD (UB), Insemnări pe cărți de cult din secolele XVII-XVIII din Crişana. De la paratext la file de istorie; Mădălin TROHONEL (UBB), Mănăstriea Lainici-file de trăire isihastă; Florin BĂTRÂNAC (UOC), Comunicare interconfesională și comuniune interetnică în BOR. Studiu de caz: Dobrogea de Sud (1923-1940); Florin ȘTEFAN (UB), 'Esse'versus 'Habere'-dualitatea voinţei umane; Florin GAȘPAR (UAV), Problema morții în gândirea părintelui Stăniloae; Cosmin LAZĂR (UAB), Instrumentalizarea embrionului uman în scopuri științifice. $O$ perspectivă interconfesională; Mihail DINU (UAB), Argumente liturgice pentru respectul faţă de embrionului uman; Trandafir VID (UBB), Psihanaliză și duhovnicie în viziunea lui Giacomo Dacquino; Raluca MOCEAN (UAB), Raimon Panikkar şi cosmoteandria; Petru CERNAT (UAIC), Elemente de antropologie prenatală în literatura creştină a secolului al II-lea; Alexandru VLAD (UAB), Creatio 'ex nihilo' în gândirea patristică a primelor veacuri creștin; Alexandru OLTEAN 
(UAB), Dialogul Bisericii cu familia postdecembristă. Defecte, efecte și afecte; Gelu PORUMB (UBB), Crizele vieții de familie - perspectivă canonică; Sorin SĂPĂLCAN (UAV), Mesajul iconografiei bisericilor de lemn din judeţele Arad şi Hunedoara; Andrei PETRACHE (UAB), Limbajul sacru al Bisericii - simbol şi icoană; Elena ONEȚIU (UBB), Simbolistica vieții în reprezentările iconografice românești; Cătălin VARGA (UBB), Răspunsul lumii ortodoxe contemporane la modelul biblic al relației Biserică-Stat: teza unei teocrații ortodoxe coregente; Cosmin CÎRSTEA (UB), Cultura, expresie a vocației omului ca 'preot al creației'; Eusebiu EȘANU (UAB), Răspândirea creștinismului în Europa, între identitate și cultură; Luminița IVANOVICI (UBB), Zalmoxis și practicile de dobândire a nemuririi potrivit textului lui Herodot; Gheorghe RĂDULESCU (UB), Biserica Scientologică - O perspectivă misionarpastorală asupra procedeelor de vindecare; Nicolae DANCO (ULBS), Neoprotestantismul între Tradiție şi tradiții; Alexandru NICODIM (ULBS), Secolul creștin în Japonia (1549-1637); Mirel GĂLUȘCĂ (UIAC), Războiul ca judecată divină în Vechiul Testament: cazul canaaniţilor; Mihaela GLIGAN (UBB), Iisus şi Baraba: un episod controversat (Mt. 27, 15-26; Mc. 15, 6-15; Lc. 23, 17-25; In. 18, 38-40); Traian FLOREA (UBB), Biserica - templu duhovnicesc - abordare exegetică a afirmației Apostolului Pavel: „,Dumnezeu nu locuiește în temple făcute de mâini omeneşti" (FA 17, 24); Ionuț HENS (UBB), Persoana Fiului lui Dumnezeu în imnul hristologic de la Coloseni 1, 15-20.

Procesul de selecție, revizie, corectare și adaptare a textelor la normele de publicare ale revistei Altarul Reîntregirii a presupus un efort considerabil, pentru care trebuie să mulțumesc în special domnului drd. Alexandru AGIGNOAEI, de la Universitatea „1 Decembrie 1918”, care a fost implicat nu numai în asigurarea logisticii și organizarea evenimentului, ci și în pregătirea acestui volum. Mulţumiri se cuvin și domnilor doctoranzi Marius CĂLDĂRARU (Universitatea din București) și Luminița IVANOVICI (Universitatea „Babeș-Bolyai) pentru contribuția lor în aducerea tuturor materialelor la forma finală.

Întrucât un singur volum ar fi fost cu neputință de manipulat, am ales soluția de a publica materialele în trei numere consecutive ale revistei Altarul Reîntregirii, în care materialele sunt, parțial, grupate tematic. 